\title{
Effect of N:P Ratio on Microalgae/Nitrifying Bacteria Community in Agro-Digestate Treatment
}

\author{
Micol BELLUCCI ${ }^{1}$, Francesca MARAZZI ${ }^{2}$, Elena FICARA ${ }^{3}$, Valeria MEZZANOTTE ${ }^{4 *}$ \\ ${ }^{1-3}$ Politecnico di Milano, DICA, Piazza L. da Vinci, 32, 20133 Milano, Italy \\ ${ }^{4}$ Università degli Studi di Milano Bicocca, DISAT, Piazza della Scienza, 1, 20126 Milano, Italy
}

\begin{abstract}
The role of $P$ content on the treatment and valorization of the liquid fraction of digestate, namely centrate, through microalgae-based technologies was evaluated in this study. The performance of four column photobioreactors, which were fed on diluted centrate with corrected (10 mg N/ mg P) and not modified (129 mg N/ mg P) N:P ratio, were monitored and compared. The results demonstrated that $P$ shortage in the centrate affected neither the total nitrogen and COD removal rate nor the volumetric biomass productivity, suggesting that expensive addition of $P$ salts is not necessary to maximize the efficiency of the process. On the contrary, the addition of $P$ to the centrate promoted the ammonia oxidation process as higher nitrite production was observed in the photobioreactors with adjusted N:P ratio than in the ones fed with the non-adjusted N:P ratio. These findings were confirmed by fluorescence in-situ hybridization and quantitative PCR assays, which revealed a higher number of ammonia-oxidizing bacteria in the microalgal suspensions cultivated on centrate with $P$ addition. In conclusion, the $N: P$ ratio in the centrate seems to have a role in controlling the nitrification process rather than in the overall nutrient removal rate and biomass productivity of the microalgae-based system.
\end{abstract}

Keywords - Ammonia oxidation; centrate; microalgae-based technology; nutrient removal; $P$ content

\begin{tabular}{|ll|}
\hline \multicolumn{2}{l}{ Nomenclature } \\
N & Nitrogen \\
P & Phosphorus \\
DM & Dry Matter \\
AD & Anaerobic Digestion \\
MAS & Microalgae-based technology \\
AOB & Ammonium Oxidising Bacteria \\
PBR & Photo-bioreactor \\
COD & Chemical oxygen demand \\
TSS & Total suspended solid \\
VSS & Volatile suspended solid \\
PCR & Polymerase chain reaction \\
\hline
\end{tabular}

* Corresponding author.

E-mail address: valeria.mezzanotte@unimib.it 


\begin{tabular}{|lll|}
\hline FISH & Fluorescence in situ identification & \\
$P_{v}$ & Volumetric biomass productivity & $\mathrm{mg} \mathrm{TSS} \mathrm{L}^{-1} \mathrm{~d}^{-1}$ \\
$r r_{j}$ & Volumetric removal rate for contaminant $i$ & $\mathrm{mg} \mathrm{L}^{-1} \mathrm{~d}^{-1}$ \\
$\eta_{j}$ & Removal efficiency for contaminant $i$ & - \\
\hline
\end{tabular}

\section{INTRODUCTION}

In Lombardy, which is the most populated region of Northern Italy, $69 \%$ of the land is employed for agricultural purposes; more than 50000 farms are present breeding ca. 1.5 million cows and 4 million pigs. Therefore, proper management of agricultural and livestock wastewaters is required to protect the environment and to comply with the European Nitrate Directive (91/676/CEE). To reduce treatment costs and recover energy, anaerobic digestion (AD) is largely applied, with around 500 operative biogas plants producing more than $350 \mathrm{MW}$. However, AD produces a nitrogen rich digestate with concentrations ranging from 44 to $120 \mathrm{~g} \mathrm{~N} \mathrm{~kg}^{-1} \mathrm{DM}[1]$.

Microalgae-based technology (MAS) is now under development since microalgae assimilate nutrients while growing, support bacteria activity via photo-oxygenation, and generate biomass that can be further used as a feedstock for the production of bioenergy and biofertilizers.

The production of bioenergy as biogas or biodiesel from photosynthetic organisms (cyanobacteria and microalgae) was suggested in the 1950s [2], but only recently this potential has risen again motivated by the search for renewable energy sources and effective circular solutions [3]. Indeed, methane yield from microalgae is reported to range from $166 \mathrm{~mL} \mathrm{gVS}^{-1}$ in Chlorella minutissima to $380 \mathrm{~mL} \mathrm{gVS}^{-1}$ in Chlamydomonas spp. [4]. The higher values are comparable with the yields from other crops typically used for biogas production. When applied to soil, microalgal biomass improves soil fertility and structure, and can produce plant growth hormones, polysaccharides, antimicrobial compounds and other metabolites to stimulate plant growth. The effects of cyanobacteria and green algae as biofertilizers in terms of improving fertility and quality of soil and promoting plant growth is going to be a new application in modern agriculture [5], [6]. Microalgal biomass is also a potential source for producing bioplastics, and can be used directly, as well as a feedstock for secondary processes [7].

Several research groups are focusing on the feasibility of remediation and resource recovery from various agro-industrial wastewaters, including the liquid fraction of digestate [8]-[10]. In these bioremediation systems, complex consortia of microalgae and bacteria develop and nitrogen conversion is carried out by microalgae and nitrifying bacteria (ammonia which oxidize ammonia to nitrate via nitrite [10]-[12]. It is well known that microalgae satisfy the oxygen requirement of bacteria by generating oxygen through the photosynthesis [13], but the understanding of the interaction between these two types of microbes, as well as the role of oxidizing bacteria and nitrite oxidizing bacteria on the speciation of nitrogen in the system is still limited. Several factors, including light, temperature, and nutrient availability, seem to regulate the assembling of the microalgal-bacteria consortium, as well as the growth and biodegradation activity of each type of microbe [14]. 
It is generally assumed that phosphorus availability has a key role being the limiting factor for the growth of microalgae [15]. According to Redfield (1934), the optimal N:P molar ratio for the growth of algae is 16 , though the microalgae are quite flexible and can adapt within a large range of $\mathrm{N}: \mathrm{P}$ ratio [8], [16].

The aim of this work was to evaluate if $\mathrm{P}$ availability affects nitrogen removal efficiency and biomass productivity in a microalgae-based system by focusing on the effect of the N:P ratio on the activity and function of microalgae and ammonia oxidizing bacteria (AOB). As growth medium, the liquid fraction of an agro-industrial digestate, referred to as 'centrate' (i.e. obtained by digestate centrifuging), from a typical farm situated in Northern Italy was used.

\section{MAterials ANd Methodology}

\subsection{Photobioreactors set up and operation}

Four parallel plexiglass columns (height $35 \mathrm{~cm}$ and diameter $10 \mathrm{~cm}$, working volume $1.5 \mathrm{~L}$ ) were set up as photobioreactors (PBRs) (Fig. 1).

Columns were mixed by magnetic stirrers and light was provided by fluorescent lamps (FLUORA model, OSRAM, Munich, Germany) providing a light intensity of $40 \mathrm{~W} \mathrm{~m}^{-2}$ and working according to $12 / 12 \mathrm{~h}$ dark/light periods. PBRs were operated at room temperature $\left(15-32{ }^{\circ} \mathrm{C}\right.$, average $\left.=27 \pm 2{ }^{\circ} \mathrm{C}\right)$. Even if temperature can affect biological kinetics, in this case it was not set constant as it is not relevant to the specific purpose of the research; $\mathrm{pH}$ was not controlled.

The PBRs were inoculated with a consortium of microalgae dominated by Chlorella spp. e Scenedesmus spp. $\left(500 \mathrm{~mL}\right.$ with an $\left.\mathrm{OD}_{680}=1.6\right)$, which were previously grown spontaneously, without any selection, on the same centrate used for the experiments. The PBRs were fed on a diluted centrate collected from a full-scale biogas plants fed on the solid fraction of piggery wastewater, energy crops, and agricultural wastes (three anaerobic digesters of $3000 \mathrm{~m}^{3}$ each, total hydraulic retention time HRT $\approx 30$ days, $\mathrm{T}=40{ }^{\circ} \mathrm{C}$ ). The centrate was diluted (6.8 folds) with tap water in order to achieve the following characteristics: $\mathrm{NH}_{4}^{+}-\mathrm{N}=200 \mathrm{mg} \mathrm{N} \mathrm{L}^{-1}, \mathrm{NO}_{3}^{-}-\mathrm{N}=2.3 \mathrm{mg} \mathrm{N} \mathrm{L}^{-1}, \mathrm{PO}_{4}^{-}-\mathrm{P}=1.6 \mathrm{mg} \mathrm{P} \mathrm{L}{ }^{-1}$, $\mathrm{COD}=790 \mathrm{mg} \mathrm{L}^{-1}, \mathrm{TSS}=190 \mathrm{mg} \mathrm{L}^{-1}$. Feeding was provided in a semi-continuous mode (twice per week) for 103 days, at a fixed average HRT of 10 days.

Two PBRs (NC1 and NC2) were fed on the unmodified diluted centrate (i.e. with a N/P ratio of $129 \mathrm{mg} \mathrm{mg}^{-1}$, corresponding to a molar ratio of 58, while the other two PBRs $(\mathrm{C} 1$ and $\mathrm{C} 2$ ), were fed on $\mathrm{P}$-supplemented diluted centrate, obtained by adding $\mathrm{KH}_{2} \mathrm{PO}_{4}$ to the diluted centrate to achieve a N/P ratio of $10 \mathrm{mg} \mathrm{mg}^{-1}$. The final value corresponded to a molar ratio of 4.5, about four times lower than the Redfield ratio, and was chosen in order to maximize the effects of the change. Samples were collected twice a week for chemical-physical and microbiological analyses. 


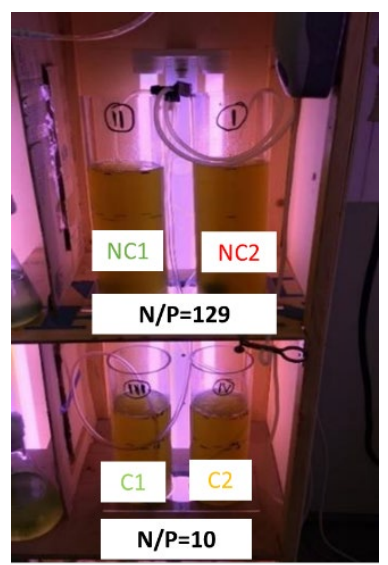

Fig. 1. The lab-scale photobioreactors used for the experiments.

\subsection{Analytical methods}

Nutrient removal efficiency and microalgal productivity were assessed based on the concentration of the different forms of $\mathrm{N}$, of $\mathrm{P}$, and of biomass. The determination of $\mathrm{NH}_{4}{ }^{+}-\mathrm{N}, \mathrm{NO}_{2}^{-}-\mathrm{N}, \mathrm{NO}_{3}^{-}-\mathrm{N}, \mathrm{PO}_{4}^{-}-\mathrm{P}$ concentrations and soluble $\mathrm{COD}$ were carried out by spectrophotometric test kits (Hach-Lange, DR6000TM UV VIS Spectrophotometer, Hach Lange LT200 Dry thermostat) on filtered $(0.45 \mu \mathrm{m})$ samples of the microalgal suspensions. Total suspended and volatile solids (TSS and VSS) were measured in duplicate according to Standard Methods for the Examination of Water and Wastewater (APHA). The elemental composition of the dried biomass was determined by a Perkin Elmer CHNS/O analyzer2400series II. Absorbance and turbidity were measured spectrophotometrically at $680 \mathrm{~nm}$ wavelength in $1 \mathrm{~cm}$ cuvette and $860 \mathrm{~nm}$ wavelength in $5 \mathrm{~cm}$ cuvette, respectively (DR6000TM UV VIS, Hach Lange, Germany). Temperature and pH were routinely checked using a multiparametric probe (XS PC 510 Eutech Instruments, Stevensville, USA).

\subsection{Microalgal counting and identification}

Microalgal populations were monitored for strain composition and cell counts over time. An adequate dilution of the microalgal suspension was placed in a hemocytometer (Marienfieled, Germany) and the microalgal cells were counted by an optical microscope with a 40x objective (B 350, Optika, Italy). The total cell number was calculated from the average of 6 squares $\left(1 \mathrm{~mm}^{2}\right)$ readings. During the counting, each algal cell was identified according to its morphology.

\subsection{Molecular methods}

Aliquots of microalgal suspensions $(1.5 \mathrm{~mL})$, which were collected at days 44, 51, 85 and 99 , were immediately frozen at $-20{ }^{\circ} \mathrm{C}$ after sampling for quantitative PCR assays. Prior to DNA extraction, the thawed samples were centrifuged at $13000 \mathrm{rpm}$ for $5 \mathrm{~min}$; the resulting pellets were washed twice with $1 \mathrm{~mL}$ of distilled sterile water. Then, the DNA extraction was carried out using Power Soil DNA isolation kit (MO BIO, USA) according to the manufacturer's instructions. In the final step, the DNA was eluted with $100 \mu \mathrm{L}$ sterile water, 
its quality and concentration were checked using a spectrophotometer (BioTek EON microplate spectrophotometer; BioTek, Italy). All DNA samples were then frozen at $-20{ }^{\circ} \mathrm{C}$ until PCR analyses.

The number of total bacteria and ammonia oxidizing bacteria was evaluated by quantitative PCR (qPCR). Primers targeting the 16S ribosomal RNA (rRNA) genes of bacteria (primer set: 357-F (5'-CCTACGGGAGGCAGCAG 3') and 907-R (5'-CCGTCAATTCCTTTGAGT TT-3') [17], [18] and primers targeting the ammonia monooxygenase structural gene amoA of AOB (primer set: amoA-1F (5'-GGGG TTTCTACTGGTGGT) and amoA-2R (5'-CCCCTCKGSAAAGCCTTCTTC) [19] were used. In each PCR reaction (total volume $20 \mu \mathrm{L}) 3 \mu \mathrm{L}$ of DNA was added to a mix solution containing Power SYBR Green PCR Master Mix (Applied Biosystems, USA) and $100 \mathrm{nM}$ of each primer. The PCR cycles were performed on AB 7300 Real-Time PCR System (Life Technologies, Italy) as described in Bellucci et al. (2015) and Marazzi et al. (2019) [20], [21]. The 16S rRNA gene copy numbers were then converted to equivalent cell numbers assuming that an average of 4.2 rRNA operon exists in each bacterial cell; whereas the number of AOB was estimated by considering 2 copies of amoA gene in each AOB cell [22], [23].

AOBs were also detected directly into the microalgal suspensions by combining Fluorescence In-Situ Identification (FISH) and fluorescent microscopy. Freshly collected samples were stored in ethanol (sample/ethanol ratio $=1: 2[\mathrm{v} / \mathrm{v}]$ ) at $-20^{\circ} \mathrm{C}$ prior to fixation, which was then performed using $4 \%$ paraformaldehyde fixative solution (PFA) as described elsewhere [23], [24]. Hybridization assays were then performed as previously described [25] with a mixture of probes targeting the 16s rRNA of different populations of AOB (Nso1225, NEU, and 6a192) [23], [26]. The hybridized cells were then visualized with a 40x objective by Zeiss fluorescence microscope (Axio Scope HBO 50).

\subsection{Data processing and statistical analyses}

Performance parameters were computed from the concentrations of each relevant component either in the influent digestate (IN) or in the algal suspension (OUT) measured between two consecutive feedings (i.e. at time $t_{i-1}$ and $t_{i}$ ) and considering the volume of the $\operatorname{PBR}\left(V_{\mathrm{C}}\right)$ and the fraction of it that was withdrawn and substituted with fresh feed $\left(V_{\mathrm{IN}}\right)$.

As for the volumetric productivity $\left(P_{\mathrm{V}}\right)$, TSS values (in $\left.\mathrm{mg} \mathrm{L}^{-1}\right)$ were used in Eq. (1).

$$
P_{\mathrm{V}, t_{i}}=\frac{V_{\mathrm{C}} \times T S S_{\mathrm{OUT}, t_{i}}-\left[\left(V_{\mathrm{C}}-V_{\mathrm{IN}}\right) \times T S S_{\text {OUT }, t_{i-1}}+V_{\mathrm{IN}} \times T S S_{\mathrm{IN}}\right]}{V_{\mathrm{C}}}
$$

As for volumetric removal rates $\left(r r_{j}\right)$, the concentration of each relevant contaminant $\left(C_{j}\right.$ with $j=\mathrm{COD}, \mathrm{N}$-forms, P) were used in Eq. (2).

$$
r r_{j, t i}=\frac{\left[\left(V_{\mathrm{C}}-V_{\mathbb{N}}\right) \times C_{j, \text { OUT }, t_{i-1}}+V_{\mathrm{IN}} \times C_{j, \mathrm{~N}}\right]-V_{\mathrm{C}} \times C_{j, \mathrm{OUT}, t_{i}}}{V_{\mathrm{C}}}
$$

It should be noted that in the case of oxidized nitrogen forms (nitrite or nitrate), removal rates were negative, indicating that those components were produced by the microalgaebacteria consortium. In this case, production rates $\left(p r_{\mathrm{N}-\mathrm{NOx}}\right)$ are reported $\left(p r_{\mathrm{N}-\mathrm{NOx}}=-r r_{\mathrm{N}-\mathrm{NOx}}\right)$. 
Finally, removal efficiencies were computed for each relevant contaminant $\left(C_{j}\right)$ in Eq. (3).

$$
\eta_{j, t i}(\%)=\frac{C_{j, I N}-C_{j, O U T, t_{i}}}{C_{j, I N}} \times 100
$$

The efficiency of the nitrogen transfer to the atmosphere (including $\mathrm{NH}_{3}$ stripping or $\mathrm{N}_{2}$ production by denitrification) was quantified as the difference between the influent ammoniacal nitrogen and the nitrogen leaving as residual ammonium, oxidized nitrogen and assimilated nitrogen (the later estimated by assuming a $\mathrm{N}$ content of $8 \mathrm{~g} \mathrm{~N} \mathrm{~g} \mathrm{TSS}^{-1}$ as measured by elemental analyses) in Eq. (4).

$$
\eta_{\mathrm{N}, \mathrm{atm}}(\%)=\left(1-\frac{r r_{\mathrm{N}-\mathrm{NH} 4}+p r_{\mathrm{N}-\mathrm{NOx}}+0.08 \times P_{\mathrm{V}}}{V_{\mathrm{IN}} \times C_{\mathrm{N}-\mathrm{NH} 4, \mathrm{IN}}}\right) \times 100
$$

To compute the average performances of the system, these time series were averaged within operationally stable periods. In detail, the initially transient phase was disregarded $\left(t_{0}-t_{15}\right)$ as well as a transient non-stationary phase between $t_{60}$ and $t_{80}$, as it will be more thoroughly discussed later on.

Statistical analyses were conducted with the open source tool of R (3.6.0) Rstudio (Version 1.1.383) and the data analysis tool of Excel 2019. The statistical significance of the reproducibility ( $p$-value $>0.05$ ) of duplicate PBRs, as well as the differences $(p$-value $<0.05)$ between the two conditions ( $\mathrm{P}$ addition or not), were assessed by pairwise t-paired tests. The significance of the influence of $\mathrm{P}$ addition on the performance and microbial population evolution in the PBRs was also confirmed by one-way analyses of variance (ANOVA).

\section{Results}

\subsection{Biomass productivity}

In Fig. 2, the time trend of the optical density $\left(\mathrm{OD}_{680}\right)$, as a proxy parameter of the microalgae concentration in the PBR, is shown. The $\mathrm{OD}_{680}$ data series were similar in duplicate PBRs ( $p$-value $>0.1$, paired-t tests). After an initial colonization phase lasting approximately 2 weeks, the algae concentration stabilized until day 60. Fluctuations were however observed mostly due to variations in room temperature. The $\mathrm{OD}_{680}$ trend also evidences a significant decline of the microalgal biomass concentration between days 57 and 68 , when a severe bloom of the filamentous cyanobacteria Oscillatoria sp. occurred, probably favoured by a decrease of the room temperature to $15^{\circ} \mathrm{C}$. The extent of the reduction in biomass concentration was similar in both $\mathrm{NC}$ and $\mathrm{C}$ PBRs, possibly suggesting that $\mathrm{P}$ availability did not significantly affect the cyanobacteria. Once the filaments of Oscillatoria sp. were manually removed, the microalgae density increased again, and a new steady state condition was reached from day 80 to the end of the experimentation. 


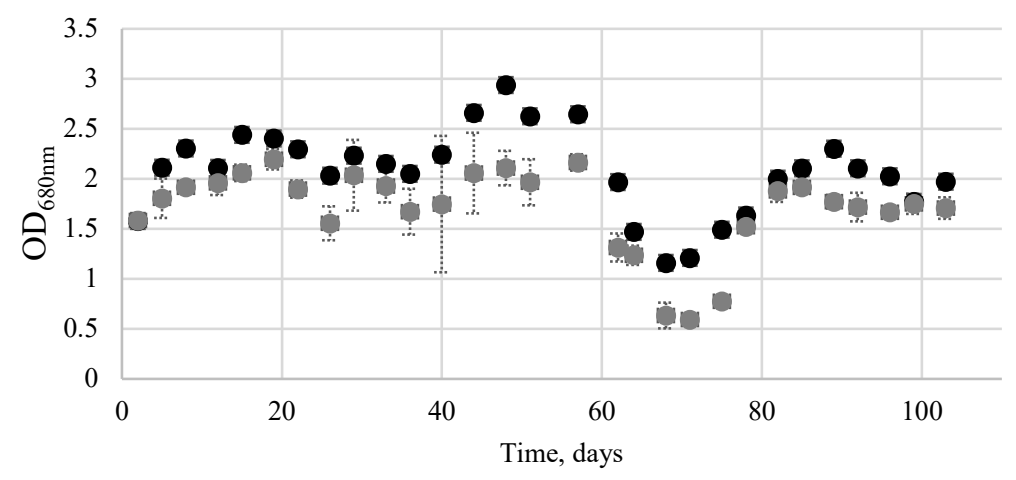

Fig. 2. Averaged $\mathrm{OD}_{680 \mathrm{~nm}}$ detected in $\mathrm{NC}$ (black) and $\mathrm{C}$ (grey) over time. Error bars represent the standard deviation.

On the overall, these data suggest that microalgae could grow in all systems demonstrating that centrate is a suitable substrate for microalgal cultivation. A slightly higher $\mathrm{OD}_{680}$ was measured in NC reactors compared to $\mathrm{C}$ ones ( $p$-value $<0.05$; t-paired tests and ANOVA). From TSS data, the overall biomass productivity $\left(P_{\mathrm{v}}\right)$ was assessed, and average values of $64 \pm 29 \mathrm{mg} \mathrm{DW} \mathrm{L}^{-1} \mathrm{~d}^{-1}$ and $53 \pm 30 \mathrm{mg} \mathrm{DW} \mathrm{L}^{-1} \mathrm{~d}^{-1}$ in $\mathrm{NC}$ and $\mathrm{C}$ reactors, respectively, were computed. The slightly higher value of $P_{\mathrm{v}}$ in the NC PBRs was in fact non-significant ( $p$-value $>0.31$, ANOVA), suggesting that $P_{\mathrm{v}}$ is not affected by the $\mathrm{N}: \mathrm{P}$ ratio in the feed.

\subsection{Bioremediation performance}

Table 1 summarizes the main bioremediation performances of the PBRs. All data series (COD, N-forms and P) were first checked for replicability by applying a paired-t test to series collected in replicate PBRs. Indeed, all time-series were similar in duplicate reactors $(p$-value $>0.05)$. Specifically, removal rates $\left(r r_{i}\right)$ and removal efficiencies $\left(\eta_{i}\right)$ were computed during the steady state performance of the PBRs.

As for COD, all PBRs were effective, removing approximately $65 \%\left(45 \pm 11 \mathrm{mg} \mathrm{L}^{-1} \mathrm{~d}^{-1}\right)$ the organic components in the digestate. The observed COD removal can be attributed to the activity of heterotrophic bacteria and/or the potential mixotrophic growth of microalgae. Available data do not allow distinguishing among these two removal mechanisms. Both average $r r_{\mathrm{COD}}$ and average $\eta_{j}$ were similar in all PBRs ( $p$-value $=0.95$, ANOVA) regardless of the $\mathrm{N}: \mathrm{P}$ ratio in the feed, suggesting that COD removal was not affected by the $\mathrm{P}$ availability.

As for $\mathrm{P}$, average $r r_{\mathrm{P}}$ were similar in duplicate reactors ( $p$-value $>0.1$, t-paired tests), but higher in $\mathrm{C}$ reactors than in $\mathrm{NC}$ ones. The residual $\mathrm{P}$ concentrations in the effluents averaged $0.5 \pm 0.4 \mathrm{mg} \mathrm{L}^{-1}$ and $11 \pm 4 \mathrm{mg} \mathrm{L}^{-1}$ in $\mathrm{NC}$ and $\mathrm{C}$ PBRs, respectively and with a higher $\eta_{\mathrm{P}}$ for $\mathrm{NC}$ than for $\mathrm{C}$ reactors. However, considering the different $\mathrm{P}$ loading rate, $\mathrm{C}$ reactors removed from 6.2 times more $\mathrm{P}$ than $\mathrm{NC}$ reactors (see Table 1). By computing the ratio between $\operatorname{rr}_{\mathrm{P}}$ and $P_{\mathrm{V}}$, one can see the average $\mathrm{P}$ content was $0.2 \%$ and $1.4 \%$ of TSS for NC and C reactors, respectively. 
Table 1. Bioremediation Performances: Removal or Production Rates $\left(\mathrm{RR}_{\mathrm{I}}, \mathrm{PR}_{\mathrm{I}} \mathrm{IN}\right.$

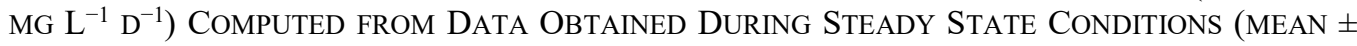
StAndard Deviation, $N=17)$. Removal EFFICIENCIES $\left(\eta_{I}\right)$ FOR THE PBRs ARE Also REPORTED.

\begin{tabular}{llllllllll}
\hline PBR & $\boldsymbol{r r}_{\mathrm{Ntot}}$ & $\boldsymbol{r}$ & $\boldsymbol{r} \boldsymbol{r}_{\mathrm{P}}$ & $\boldsymbol{r} \boldsymbol{r}_{\mathrm{N}-\mathrm{NH} 4}$ & $\boldsymbol{p} \boldsymbol{r}_{\mathrm{N}-\mathrm{NO} 3}$ & $\boldsymbol{p} \boldsymbol{r}_{\mathrm{N}-\mathrm{NO} 2}$ & $\eta_{\mathrm{N}, \mathrm{atm}}$ & $\eta_{\mathrm{N}}$ & $\boldsymbol{\eta}_{\mathrm{P}}$ \\
\hline NC1 & $6.2 \pm 7.8$ & $0.05 \pm 0.19$ & $48 \pm 11$ & $8.8 \pm 8.1$ & $0.4 \pm 0.6$ & $2.2 \pm 3.5$ & 19 & 34 & 85 \\
$\mathbf{N C 2}$ & $8.7 \pm 4.7$ & $0.07 \pm 0.14$ & $47 \pm 11$ & $10.9 \pm 3.8$ & $0.4 \pm 0.6$ & $1.5 \pm 4.7$ & 19 & 38 & 92 \\
$\mathbf{C 1}$ & $9.6 \pm 7.1$ & $0.79 \pm 1.04$ & $48 \pm 12$ & $16.5 \pm 4.5$ & $0.5 \pm 0.7$ & $5.4 \pm 8.6$ & 29 & 47 & 46 \\
$\mathbf{C 2}$ & $10 \pm 7$ & $0.95 \pm 1.08$ & $45 \pm 13$ & $17.5 \pm 2.6$ & $0.6 \pm 0.7$ & $6.9 \pm 6.7$ & 25 & 43 & 45 \\
$\boldsymbol{p}$-values & 0.37 & 0.00058 & 0.84 & $<0.000$ & 0.79 & 0.037 & & & \\
$\begin{array}{l}\text { Influence } \\
\text { of P }\end{array}$ & No & Yes & No & Yes & No & Yes & & & \\
\hline
\end{tabular}

As to nitrogen, a detailed analysis of the $\mathrm{N}$ compounds in the PBRs effluent (Fig. $3 \mathrm{NC}$ and Fig. $3 \mathrm{C}$ ) as well as the removal rates of the different $\mathrm{N}$-forms (Table 1) revealed some interesting differences. Although the $r r_{\text {Not }}$ (where $\mathrm{N}_{\text {tot }}=\mathrm{N}-\mathrm{NH}_{4}{ }^{+}+\mathrm{N}_{-} \mathrm{NO}_{2}{ }^{-}+\mathrm{N}_{-} \mathrm{NO}_{3}{ }^{-}$) was similar in all PBRs ( $p$-values $>0.05$, t-paired tests and ANOVA), $r r_{\mathrm{N}-\mathrm{NH} 4}$ was higher in $\mathrm{C}$ $\left(17 \pm 3.7 \mathrm{mg} \mathrm{L}^{-1} \mathrm{~d}^{-1}\right)$ than in $\mathrm{NC}\left(9.8 \pm 6.4 \mathrm{mg} \mathrm{N} \mathrm{L}^{-1} \mathrm{~d}^{-1}\right)$ reactors ( $p$-values $=0.005$ ANOVA) Similarly, $p r_{\mathrm{N}-\mathrm{NO} 2}$ in $\mathrm{C}\left(6.2 \pm 7.6 \mathrm{mg} \mathrm{N} \mathrm{L}^{-1} \mathrm{~d}^{-1}\right)$ was higher than in $\mathrm{NC}\left(1.8 \pm 4 \mathrm{mg} \mathrm{N} \mathrm{L}^{-1} \mathrm{~d}^{-1}\right)$, $\left(p\right.$-values $=0.037$ ANOVA), while $p r_{\mathrm{N}-\mathrm{NO} 3}$ was practically negligible in all reactors $(0.5 \pm$ $\left.0.6 \mathrm{mg} \mathrm{N} \mathrm{L}^{-1} \mathrm{~d}^{-1}\right)$. Even the contribution of $\mathrm{N}$ transfer to the atmosphere was found to be different since it accounted for the $19 \pm 0.1 \%$ and $27 \pm 3 \%$ of the total $\mathrm{NH}_{4}{ }^{+}-\mathrm{N}$ removal in $\mathrm{NC}$ and $\mathrm{C}$, respectively.

\section{$\mathrm{NC}$}

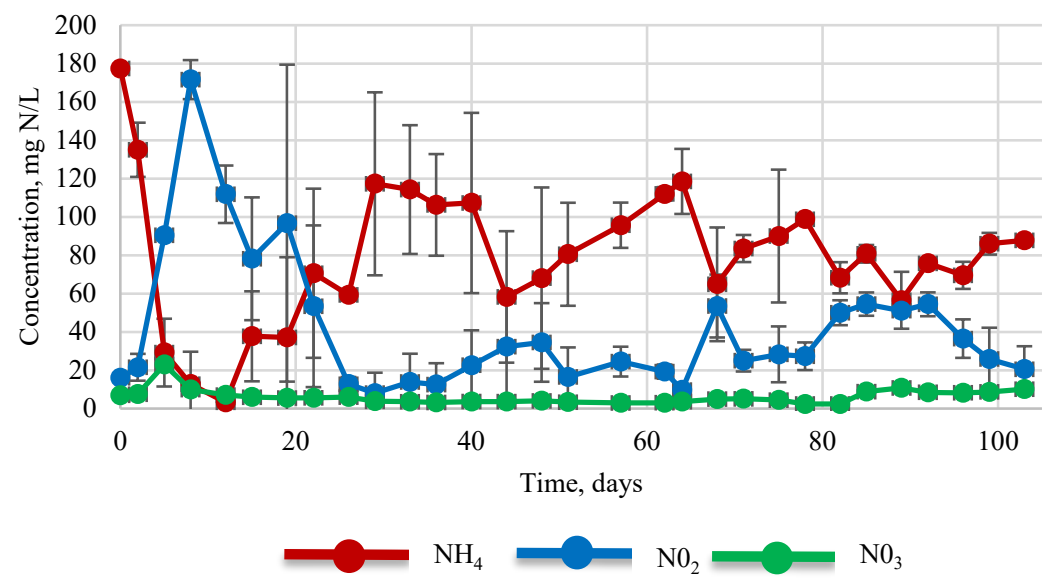

Fig. 3 NC. Averaged concentrations of ammonia (red circles), nitrite (blue diamonds) and nitrate (green triangles) measured over time in NC PBRs measured over time. Error bars represent the standard deviation. 


\section{$\mathrm{C}$}

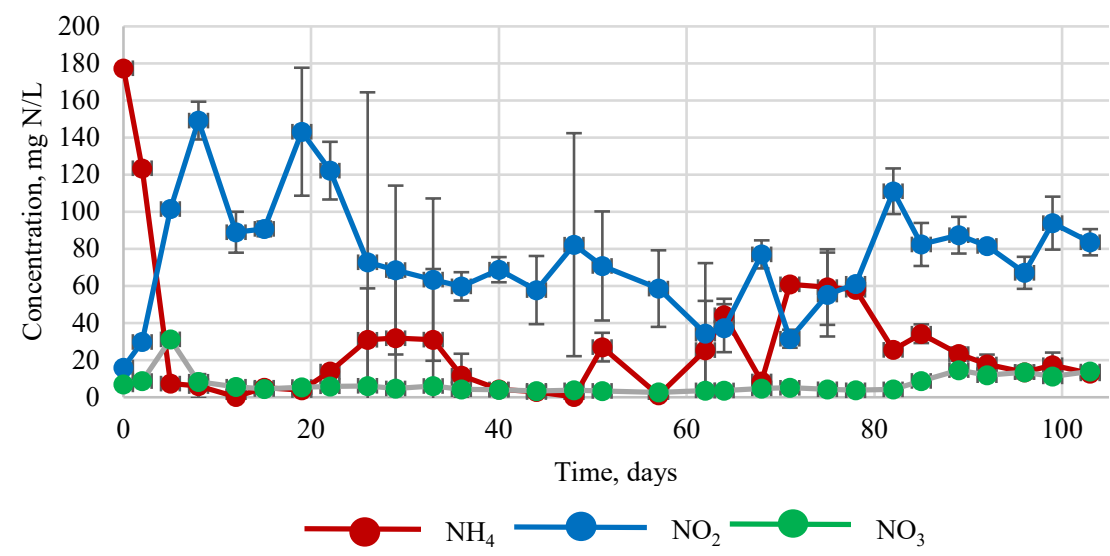

Fig. 3 C. Averaged concentrations of ammonia (red circles), nitrite (blue diamonds) and nitrate (green triangles) measured over time in C PBRs measured over time. Error bars represent the standard deviation.

As stated before, $\mathrm{pH}$ was not controlled and was on average $8.9 \pm 0.7$ in NC reactors and $7.3 \pm 1.5$ in $\mathrm{C}$ reactors. The lower $\mathrm{pH}$ in $\mathrm{C}$ than in $\mathrm{NC}$ was probably due to the higher ammonia oxidation activity in $\mathrm{C}$.

\subsection{Microbial community structure}

Microalgae counts ranged between $2.8 \times 10^{6}$ and $3.3 \times 10^{7}$ cells $\mathrm{mL}^{-1}$. In all PBRs, the microalgal community was dominated by Chlorella spp. ( $>90 \%$ of the total community) most of the time, while Scenedesmus spp., ranging between $7.5 \times 10^{5}$ and $5.7 \times 10^{6}$ cells $\mathrm{mL}^{-1}$, was detected only during the second part of the experimentation, i.e. after the recovery from the cyanobacterial bloom.

FISH assays were performed before the cyanobacterial bloom and at the end of the experiment (Fig. 4).
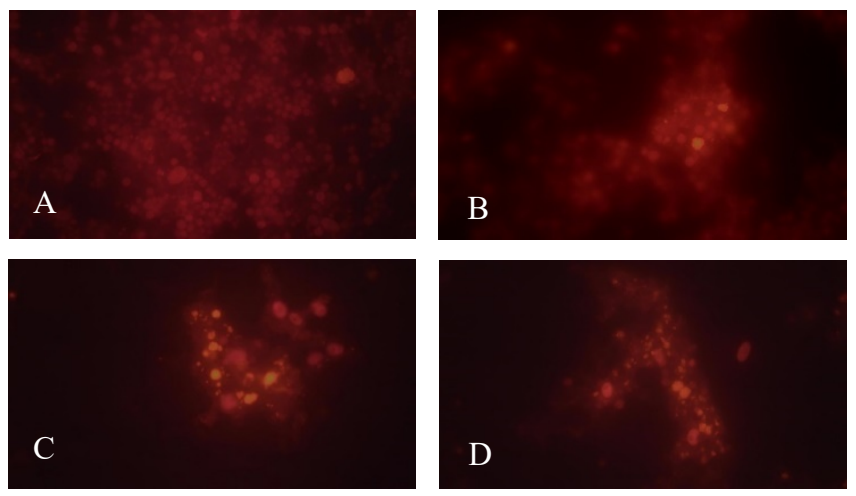

Fig. 4. AOB colonies (bright red) detected in microalgal aggregates in $\mathrm{NC}$ ( $\mathrm{A}$ and $\mathrm{B}$ ) and $\mathrm{C}(\mathrm{C}$ and $\mathrm{D}) \mathrm{PBRs}$ at days 99 by FISH assay. 
It can be observed that the $\mathrm{N}: \mathrm{P}$ correction promoted the growth and activity of $\mathrm{AOB}$ as they were visibly more abundant in $\mathrm{C}$ than in NC. Quantitative analyses (Fig. 5) confirmed that the number of $\mathrm{AOB}$ in the $\mathrm{C}$ reactors were almost $1 \log$ higher than in $\mathrm{NC}(p$-value $<0.05)$ demonstrating that $\mathrm{AOB}$ were favoured by the larger $\mathrm{P}$ availability. On the contrary, the total number of bacteria which ranged between $7.9 \times 10^{6}$ and $9.7 \times 10^{6}$ cells $\mathrm{mL}^{-1}$ was not influenced by the $\mathrm{N}: \mathrm{P}$ ratio.

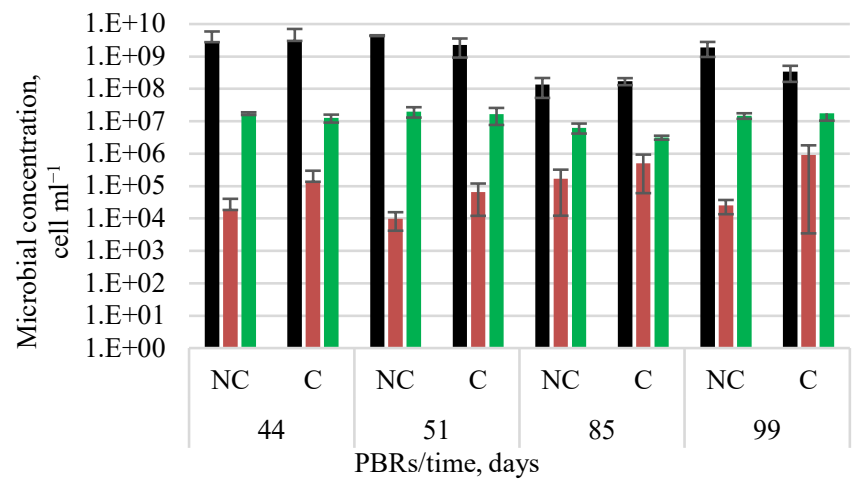

Fig. 5. Cell counts for total bacteria (black), AOB (red) and microalgae (green) in NC and C photobioreactors detected before the cyanobacterial bloom (days 44 and 51) and at the end of the trial (days 85 and 95).

Nevertheless, a reduction of the total bacterial abundance was observed after the cyanobacterial bloom ( $p$-value $<0.04$ ANOVA). These findings suggest that the microalgae produced enough oxygen to sustain the growth, not only of the AOB, but also of the heterotrophic bacteria. Yet, the growth of the heterotrophs was not limited by $\mathrm{P}$ shortage as similar and constant COD removal rate was observed in all PBRs. Nevertheless, a decline of the total bacterial number was observed after the bloom of Oscillatoria sp, suggesting that this cyanobacterium might release some antibacterial compounds [27].

\section{Discussion AND CONCLUSIONS}

The objective of this study is to assess the role of $\mathrm{P}$ content on the performance of microalgal-based technologies treating agricultural and livestock wastewaters with unbalance $\mathrm{N}$ :P ratio, such as the centrates. To this purpose, the microalgal growth and evolution, COD and nutrient removal rates, as well the nitrogen removal pathways of column PBRs fed on diluted centrate with and without the supplementing of $\mathrm{P}$ salts were monitored and compared.

The above presented results clearly demonstrate that the microalgal productivity and total nitrogen removal were independent of the concentration of $\mathrm{P}$ in the centrate. An averaged $P_{\mathrm{V}}$ of $59 \mathrm{mg} \mathrm{TSS} \mathrm{L}{ }^{-1} \mathrm{~d}^{-1}$ of microalgal biomass was measured, while the nitrogen removal rate was ca. $10 \mathrm{mg} \mathrm{N} \mathrm{L}^{-1} \mathrm{~d}^{-1}$ in all PBRs. The calculated $\mathrm{P}$ content in the biomass suggests that the microalgae-bacteria biomass could adapt to $\mathrm{P}$ shortage without detrimental effects on the biomass productivity. Indeed, the ability of the algae to change their internal $\mathrm{N}: \mathrm{P}$ ratio according to the environmental conditions was already reported [16].

These results are in agreement with laboratory and pilot scale studies in which centrate with diverse N:P ratios were used as microalgae cultivating medium. Data of this experimentation 
therefore confirm that $\mathrm{P}$ was not the limiting factor in microalgae growth as it was not in other experimentations testing centrate both in indoor and outdoor conditions [10], [15], [28] being light availability the typical limiting factor. Therefore, the practice of adding expensive $\mathrm{P}$ salts to optimize the process could be avoided without hampering biomass productivity.

Similarly, P availability did not affect the presence of heterotrophic bacteria. On the contrary, the N:P ratio did affect the nitrogen removal pathways. The addition of $\mathrm{P}$ in the centrate boosted the ammonia oxidation process as shown by the higher nitrite production in $\mathrm{C}$ than in NC reactors, and confirmed by results of the molecular assays. Nitrification, especially when stopped at the level of nitrite, is undesired in many microalgal cultivation technologies aiming to produce microalgal biomass, since AOB compete for nutrients and $\mathrm{CO}_{2}$ with microalgae, and also they produce nitrite that can inhibit microalgal growth [29]. On the other hand, in wastewater treatment the synergy between microalgae and nitrifiers can be considered an advantage to reduce aeration costs. The role of $\mathrm{P}$ in controlling nitrification in microalgae-bacteria consortia was already reported in batch cultivation tests using centrate with diverse $\mathrm{N}: \mathrm{P}$ ratio $\left(3-79{\left.\mathrm{gN} \mathrm{gP}^{-1}\right)}^{2}\right.$ [15]. The present study confirms that AOB are more sensitive to $\mathrm{P}$ shortage than microalgae also in PBRs operated in semi-continuous mode for long time. Although $\mathrm{P}$ shortage did not result in the washing out of $\mathrm{AOB}$, nonetheless their concentration was depressed in NC PBRs. Indeed, a different affinity for P of the two types of microbes (microalgae and $\mathrm{AOB}$ ) can be used as selective pressure to manipulate the microbial community assembly and function.

The following main conclusions can be finally be drawn:

1. Centrate can be used as a source of nutrients to grow a stable microalgae-bacteria consortium and interesting removal efficiencies as for N, P and COD were achieved; the $\mathrm{N}: \mathrm{P}$ ratio (up to $129 \mathrm{mg} / \mathrm{mg}$ ) is not a key factor to control the efficiency of microalgaebased technology, therefore expensive addition of $\mathrm{P}$ salts could be safely avoided;

2. P availability did not influence the activity of heterotrophic bacteria while it promoted the growth of AOB;

3. The bloom of Oscillatoria $s p$. inhibited the growth of heterotrophic bacteria and microalgae, while AOB were not affected.

\section{ACKNOWLEDGEMENTS}

The authors thank Cariplo Foundation for funding this research (Progetto Polo delle Microalghe). The authors are also grateful to Dr Luciano Beneduce for his support on the PCR assays, Eng. Tommaso Leandri and Eng. Emanuele Pirola for helping in the operation of the PBRs, and Eng. Giorgio Tornotti and Mr. Mario Drago for providing the centrate.

\section{REFERENCES}

[1] Monlau F., Sambusiti C., Ficara E., Aboulkas A., Barakat A., Carrère H. New opportunities for agricultural digestate valorization: current situation and perspectives. Energy \& Environmental Science 2015:9:2600-2621. https://doi.org/10.1039/C5EE01633A

[2] Oswald W. J., Gotaas H. Photosynthesis in sewage treatment. Transactions of the American Society of Civil Engineers 1957:122:73-105.

[3] Uggetti E., Sialve B., Trably E., Steyer J. P. Integrating microalgae production with anaerobic digestion: A biorefinery approach. Biofuels, Bioproducts and \& Biorefining 2014. https://doi.org/10.1002/bbb.1469

[4] Zabed H.M., Akter S., Yun J., Zhang G., Zhang Y., Qi X. Biogas from microalgae: Technologies, challenges and opportunities. Renewable and Sustainable Energy Reviews 2020:117:109503. https://doi.org/10.1016/j.rser.2019.109503 
[5] Guo S., Wang P., Wang X., Zou M., Liu C., Hao J. Microalgae as Biofertilizer in Modern Agriculture BT Microalgae Biotechnology for Food, Health and High Value Products, in: M. A. Alam, J.-L. Xu, Z. Wang (Eds.), Springer Singapore 2020:397-411. https://doi.org/10.1007/978-981-15-0169-2_12

[6] Ronga D., Biazzi E., Parati K., Carminati D., Carminati E., Tava A. Microalgal biostimulants and biofertilisers in crop productions. Agronomy 2019:9(4). https://doi.org/10.3390/agronomy9040192

[7] Karan H., Funk C., Grabert M., Oey M., Hankamer B. Green Bioplastics as Part of a Circular Bioeconomy. Trends in Plant Science 2019:24(3):237-249. https://doi.org/10.1016/j.tplants.2018.11.010

[8] Xia A., Murphy J. D. Microalgal cultivation in treating liquid digestate from biogas systems. Trends in Biotechnology 2016:34(4):264-275. https://doi.org/10.1016/j.tibtech.2015.12.010

[9] Franchino M., Tigini V., Varese G. C., Mussat Sartor R., Bona F. Microalgae treatment removes nutrients and reduces ecotoxicity of diluted piggery digestate. Science of the Total Environment 2016:569-570:40-45. https://doi.org/10.1016/j.scitotenv.2016.06.100

[10] Pizzera A., Scaglione D., Bellucci M., Marazzi F., Mezzanotte V., Parati K., Ficara E. Digestate treatment with algaebacteria consortia: A field pilot-scale experimentation in a sub-optimal climate area. Bioresource Technology 2019:274:232-243. https://doi.org/10.1016/j.biortech.2018.11.067

[11] Mantovani M., Marazzi F., Fornaroli R., Bellucci M., Ficara E., Mezzanotte V. Outdoor pilot-scale raceway as a microalgae-bacteria sidestream treatment in a WWTP. Science of the Total Environment 2020:710:135583. https://doi.org/10.1016/j.scitotenv.2019.135583

[12] Muñoz R., Guieysse B. Algal-bacterial processes for the treatment of hazardous contaminants: A review. Water Research 2006:40(15):2799-2815. https://doi.org/10.1016/j.watres.2006.06.011

[13] Marazzi F., Bellucci M., Fantasia T., Ficara E., Mezzanotte V. Interactions between Microalgae and Bacteria in the Treatment of Wastewater from Milk Whey Processing. Water 2020:12(1):297. https://doi.org/10.3390/w12010297

[14] Marazzi F., Ficara E., Fornaroli R., Mezzanotte V. Factors Affecting the Growth of Microalgae on Blackwater from Biosolid Dewatering. Water, Air, \& Soil Pollution 2017:228. https://doi.org/10.1007/s11270-017-3248-1

[15] Marcilhac C., Sialve B., Pourcher A. M., Ziebal C., Bernet N., Béline F. Control of nitrogen behaviour by phosphate concentration during microalgal-bacterial cultivation using digestate. Bioresource Technology 2015:175:224-230. https://doi.org/10.1016/j.biortech.2014.10.022

[16] Geider R.J., La Roche J. Redfield revisited: Variability of C:N:P in marine microalgae and its biochemical basis. European Journal of Phycology 2002:37(1):1-17. https://doi.org/10.1017/S0967026201003456

[17] Bellucci M., Botticella G., Francavilla M., Beneduce L. Inoculum pre-treatment affects the fermentative activity of hydrogen-producing communities in the presence of 5-hydroxymethylfurfural. Applied Microbiology and Biotechnology 2016:100:493-500. https://doi.org/10.1007/s00253-015-7002-6

[18] Favia G., Ricci I., Damiani C., Raddadi N., Crotti E., Marzorati M., Rizzi A., Urso R., Brusetti L., Borin S., Mora D., Scuppa P., Pasqualini L., Clementi E., Genchi M., Corona S., Negri I., Grandi G., Alma A., Kramer L., Esposito F., Bandi C., Sacchi L., Daffonchio D. Bacteria of the genus Asaia stably associate with Anopheles stephensi, an Asian malarial mosquito vector. Proceedings of the National Academy of Sciences of the United States of America 2007:104:9047-9051. https://doi.org/10.1073/pnas.0610451104

[19] Rotthauwe J. H., Witzel K. P., Liesack W. The ammonia monooxygenase structural gene amoA as a functional marker: molecular fine-scale analysis of natural ammonia-oxidizing populations. Applied and Environmental Microbiology 1997:63:4704-4712. https://doi.org/10.1128/AEM.63.12.4704-4712.1997

[20] Bellucci M., Marazzi F., Naddeo L. S., Piergiacomo F., Beneduce L., Ficara E., Mezzanotte V. Disinfection and nutrient removal in laboratory-scale photobioreactors for wastewater tertiary treatment. Journal of Chemical Technology and Biotechnology 2019:95:959-966. https://doi.org/10.1002/jctb.6010

[21] Marazzi F., Bellucci M., Fornaroli R., Bani A., Ficara E., Mezzanotte V. Lab-scale testing of operation parameters for algae based treatment of piggery wastewater. Journal of Chemical Technology and Biotechnology 2019:95:967974. https://doi.org/10.1002/jctb.5972

[22] Klappenbach J. A. rrndb: the Ribosomal RNA Operon Copy Number Database. Nucleic Acids Research 2001:29(1):181-184. https://doi.org/10.1093/nar/29.1.181

[23] Bellucci M., Curtis T. P. Ammonia-oxidizing bacteria in wastewater. Methods in Enzymology 2011:496:269-286. https://doi.org/10.1016/B978-0-12-386489-5.00011-7

[24] Amann R. I., Binder B. J., Olson R. J., Chisholm S. W., Devereux R., Stahl D. A. Combination of 16S rRNA-targeted oligonucleotide probes with flow cytometry for analyzing mixed microbial populations. Applied and Environmental Microbiology 1990:56:1919-1925. https://doi.org/10.1128/AEM.56.6.1919-1925.1990

[25] Coskuner G., Ballinger S. J., Davenport R. J., Pickering R. L., Solera R., Head I. M., Curtis T. P. Agreement between theory and measurement in quantification of ammonia-oxidizing bacteria. Applied and Environmental Microbiology 2005:6325-6334. https://doi.org/10.1128/AEM.71.10.6325-6334.2005 
[26] Bellucci M., Ofiţeru I. D., Head I. M., Curtis T. P., Graham D. W. Nitrification in hybrid bioreactors treating simulated domestic wastewater. Journal of Applied Microbiology 2013:115:621-630. https://doi.org/10.1111/jam.12233

[27] Shanmugam A., Sigamani S., Venkatachalam H., Jayaraman J. D., Ramamurthy D. Antibacterial activity of extracted phycocyanin from Oscillatoria sp. Journal of Applied Pharmaceutical Science 2017:7(3):62-67. https://doi.org/10.7324/JAPS.2017.70310

[28] Marazzi F., Bellucci M., Rossi S., Fornaroli R., Ficara E., Mezzanotte V. Outdoor pilot trial integrating a sidestream microalgae process for the treatment of centrate under non optimal climate conditions. Algal Research 2019:39:101430. https://doi.org/10.1016/j.algal.2019.101430

[29] González-Camejo J., Montero P., Aparicio S., Ruano M. V., Borrás L., Seco A., Barat R. Nitrite inhibition of microalgae induced by the competition between microalgae and nitrifying bacteria. Water Research 2020:172:115499. https://doi.org/10.1016/j.watres.2020.115499 